\title{
ORGANIZAÇÃO E PRÁTICAS SOCIOESPACIAIS NA CENTRALIDADE DA ‘RUA 44’ EM GOIÂNIA-GO
}

\author{
Marcello Soldan Garbelim \\ Doutorando em Geografia (PPGeo-UFG), Mestre em Sociologia (PPGS-UFG), Bacharel em \\ Ciências Sociais (FCS-UFG) \\ marcellosg54@hotmail.com \\ Roberta Silva Marques \\ Mestranda em Geografia (PPGeo-UFG), Licenciada em Geografia (IESA-UFG) \\ robertassm@gmail.com
}

Carlos Roberto Bernardes de Souza Júnior Doutorando em Geografia (PPGeo-UFG), Mestre em Geografia (PPGeo-UFG), Bacharel e Licenciado em Geografia (IG-UFU) carlosroberto2094@gmail.com

\begin{abstract}
RESUMO
O arranjo socioespacial da 'Rua 44' em Goiânia-GO conforma uma centralidade significativa no setor de varejo e atacado de vestuário. Esse fenômeno caracteriza-se pela sobreposição de formas e práticas socioespaciais que são dinamizadas na vida cotidiana. Entre os diferentes tipos, personagens e sujeitos sociais que atuam nesse lugar, contrapõem-se constantes tensões e negociações acerca da organização espacial. Nesse sentido, objetivase decifrar a produção da centralidade da 'Rua 44' em relação a suas formas e práticas sociais por meio das ações e motivações de quem nela efetiva sua vida. Adotou-se como orientação de método, a perspectiva regressiva-progressiva pautada em Lefebvre. Essa possibilidade metodológica colaborou na identificação de dimensões verticais e horizontais da realidade social. Para a efetivação da pesquisa, foram realizadas derivas urbanas, práticas de observação participante, entrevistas semiestruturadas e mapas mentais. Considera-se que há uma perene tensão nas dimensões políticas, econômicas e sociais dessa centralidade. Essa situação cria tensões na vida cotidiana dos sujeitos de modo a provocar uma dinâmica de percepções, concepções e vivências socioespaciais conflituosa.
\end{abstract}

Palavras-chave: Arranjo espacial. Vida cotidiana. Conflitos socioespaciais.

\section{SPATIAL ORGANIZATION AND PRATICES IN 'RUA 44’ CENTRALITY AT GOIÂNIA-GO}

\begin{abstract}
'Rua 44' sociospatial arrangement at Goiânia-GO conforms a significative centrality of the clothes' wholesale and market sector. This phenomenon is characterized by a superposition of sociospatial forms and practices that are dynamized by daily life. Between the different social types, characters, and subjects that act in this place, constant tensions and negotiations are contraposed in its spatial organization. In this sense, the objective of this essay is to decipher 'Rua 44's centrality in relation to its social forms and practices by means of the actions and motivations of those that live in it. Lefebvre's regressiveprogressive method was employed as a methodological orientation. This methodologic possibility collaborated towards the identification of horizontal and vertical dimensions of social reality. To carry out this research, urban dérives, participative observation practices, semi-structured interviews and mental maps were employed. It is considered that there is a perennial tension at political, economic and social dimensions of this centrality. This situation creates daily life tensions for its subjects and incites significant perceptions, conceptions and sociospatial dynamics of conflict.
\end{abstract}

Keywords: Spatial arrangement. Daily life. Sociospatial conflicts. 


\section{INTRODUÇÃO}

Nas metrópoles, formas ou estruturas e práticas ou dinâmicas socioespaciais possibilitam a coexistência de múltiplas centralidades urbanas. Em Goiânia, capital do Estado de Goiás, o entorno da 'Rua 44' é um centro de consumo especializado no comércio varejista e atacadista de vestuário, que durante a década de 2010, se confirmou como importante centralidade ao atrair uma ampla rede de consumidores e de revendedores de roupas do interior do Brasil.

As centralidades servem à produção, à regulação e ao consumo de capitais, bens e serviços. Mas também promovem o encontro entre pessoas, ideias e coisas pelo uso social do espaço (LEFEBVRE, 2006). A produção de uma centralidade envolve a possibilidade da articulação entre estruturas ou formas sociais ordenadoras do espaço com práticas, percepções e projeções socioespaciais dos distintos tipos, sujeitos e personagens sociais.

O presente artigo objetiva decifrar a produção socioespacial da centralidade da 'Rua 44' em Goiânia-GO, com relação às formas e práticas do espaço social, segundo ações e motivações daqueles sujeitos que nela vivem e projetam entendimentos. De modo específico busca-se caracterizar as práticas socioespaciais na 'Rua 44', enumerar os poderes sociais estruturados-estruturantes e as formas espaciais correlatas produzidas por esses sujeitos, além de delinear as projeções políticas dos personagens à cerca de conflitos socioespaciais vividos na centralidade.

A pesquisa empírica orientou-se pelos caminhos do método regressivo-progressivo, ao sugerir que para compreender a realidade social é necessário traçar um eixo horizontal e outro vertical no espaço-tempo, que se desdobram em três dimensões sociais do tempo-espaço (LEFEBVRE, 2008; MARTINS, 1996). O eixo horizontal é o cotidiano e o eixo vertical as estruturas, sendo que as vivências, as concepções e as percepções sociais são apreendidas primeiramente pela descrição do "espaço fenomênico" ou vivido no momento. Depois, na análise do vivido em regressão as concepções sociais objetivadas no espaço social estruturado na história. Em seguida, na recomposição do cotidiano presente elucidado pelo tempo-espaço percebido e concebido e visto nas dinâmicas de conflitos sociais.

Ao seguir esses passos metodológicos, os dados foram construídos com base em uma abordagem qualitativa de pesquisa, entre março e julho de 2019. A produção acadêmica e de reportagens em meios de comunicação foi revisada com intuito de identificar assuntos sensíveis à 'Rua 44'. Também foram realizadas derivas urbanas com base na proposta de Debord (1956) e práticas de observação participante centradas na perspectiva etnográfica de Magnani (2009). Em seguida foram feitas entrevistas semiestruturadas, segundo recomendações de Flick (2009), com tópicos sobre o cotidiano e as percepções subjetivas dos sujeitos. Concomitantemente efetuou-se uma dinâmica de elaboração de mapas mentais embasada na metodologia de Kozel (2008; 2013).

$\mathrm{Na}$ construção do texto, as percepções dos sujeitos são evocadas por meio da transcrição de suas falas, como discursos que legitimam os fragmentos dos engajamentos na vida social e sentidos da produção de um espaço. Por meio dos discursos de "feirantes", "vendedores", "ambulantes" e "clientes" fez-se possível explorar as dimensões da vida cotidiana, em suas dinâmicas e tramas conforme apresentada por aqueles que produzem a centralidade.

O artigo estrutura-se em três partes. Na primeira serão descritas práticas espaciais e tipos sociais na 'Rua 44'. A segunda analisa as estruturas sociais e as formas espaciais na centralidade. A última identifica as projeções sociopolíticas dos sujeitos em momentos de conflitos na centralidade.

\section{TIPOS SOCIAIS E PRÁTICAS ESPACIAIS NA CENTRALIDADE DA 'RUA 44'}

O mapa da centralidade da 'Rua 44' (Figura 1) revela um espaço compacto. A área abarca as proximidades da Rua 44 e a Avenida Contorno, além de algumas quadras e ruas adjacentes. A concentração se conforma entre o entroncamento de vias importantes de Goiânia, como a Avenida Independência, a Avenida Goiás, a Leste-Oeste e a Marginal Botafogo. No mapa também são evidenciados objetos geográficos marcadores, como o Terminal Rodoviário de Goiânia-Araguaia Shopping e a Praça do Trabalhador, que comporta a Feira Hippie. 
Figura 1 - Mapa de localização e objetos geográficos da Rua 44, Goiânia-GO.

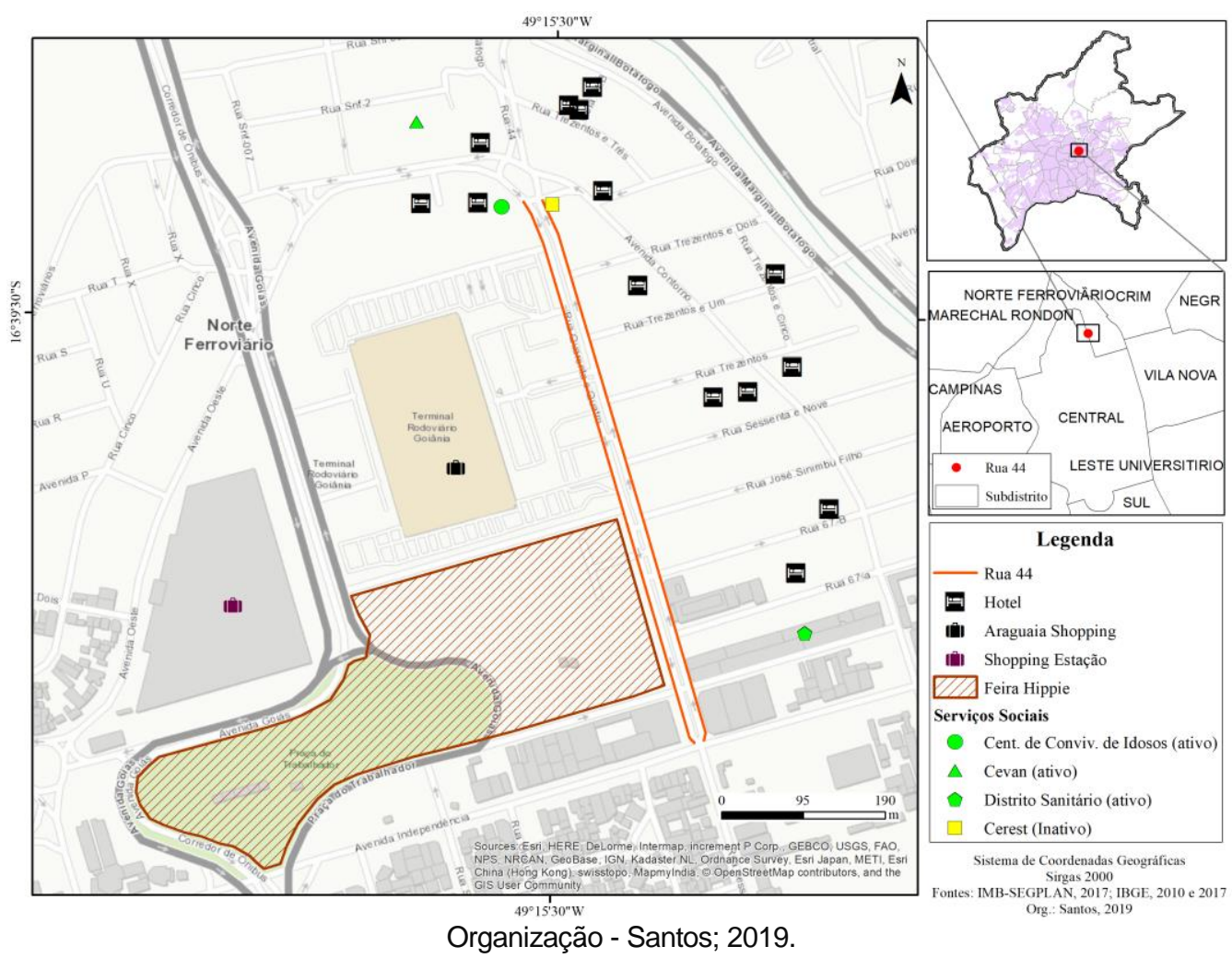

Ao colaborar com a compreensão dos ordenamentos, o mapa oportuniza inferências sobre a produção social do espaço. Mas há uma dificuldade de determinar o raio de interferência da centralidade, pois ela não se organiza exclusivamente na representação formal, também transborda dinâmicas sociais que escapam ao local imediato. É fato que adentrar a vida cotidiana em uma determinada espacialidade implica um complexo jogo de entrega.

Em um primeiro momento, ao 'derivar' na 'Rua 44' o observador se perde no cotidiano. De acordo com Bourdieu (1999, p.160, grifo no original) "o espaço social se retraduz no espaço físico, mas sempre de maneira mais ou menos confusa". A vida cotidiana, segundo Carlos (2011, p.84), "se definiria como uma totalidade apreendida nos momentos da realização do trabalho, da vida privada, do lazer, dos deslocamentos". O cotidiano assim desdobra dessas relações sociais complexas de densidade, tensões e negociações na trama entre a organização e a prática socioespacial na centralidade.

Nas práticas cotidianas da 'Rua 44' percebe-se uma miríade de cheiros, sons, sotaques, visualidades e percepções, que remetem a sobreposições de tipos sociais em suas temporalidades próprias. Como discorre Arrais (2017, p.136) "falar da rua é sempre falar dos tipos que a povoam, que a ocupam durante as horas do dia e da noite". Na centralidade da 'Rua 44' são observados diversos tipos sociais, com práticas espaciais próprias, que se sobrepõem em cenários múltiplos no cotidiano de Goiânia e região metropolitana.

Os tipos que habitam esse lugar apresentam sociabilidades e ocupam posições sociais que thes definem no cotidiano, como "feirantes", "ambulantes", "lojistas" e "vendedores", "sacoleiros" e consumidores ("clientes"). De modo peculiar esses tipos sociais possuem práticas e percepções próprias, com base na atividade ali desenvolvida. É comum identificar casos de porosidade relacional, em que determinadas fronteiras aparentemente conflitivas se revelam potencialmente fluidas. Por exemplo, existem vendedores de lojas nas galerias que também expõem produtos nas ruas junto aos "ambulantes". Alguns "feirantes" também são "lojistas" em determinadas galerias.

Essa multiplicidade fluida de tipos sociais no cotidiano realça os aspectos dinâmicos das sociabilidades. Como aponta Simmel (1971), por meio da sociabilidade surgem inúmeras formas de vida social, uma com a outra, uma pela outra ou mesmo uma contra a outra. Logo, é possível identificar maneiras específicas de vivências e de práticas sociais que emergem na relacionalidade dos tipos a esse local. 
Há uma representação corriqueira e ambígua de que o "movimento" é o fundamento das sociabilidades dos tipos sociais no cotidiano da centralidade da 'Rua 44'. Ora caótico e estressante, ora em favor de oportunizar "bons negócios", a percepção temporal do intenso "movimento" no espaço é verbalizada por termos como "correria", "agitação" e "fluxo". Essas palavras conformam um vocabulário comum partilhado entre "clientes", "lojistas", "vendedores", "ambulantes" e "feirantes". Os seguintes trechos de entrevistas destacam essa percepção,

Correria né, não tem outra palavra. Correria tanto da fiscalização, quanto pra ganhar o pão de cada dia... Porque nosso país tá difícil. - Ambulante 1.

Sou vendedora, mexo com várias pessoas, de vários Estados. Minha rotina é de casa para o trabalho... Porque aqui é muita correria. - Vendedora de Galeria 1.

A gente aqui tem uma vida muito agitada. Geralmente quem trabalha na 44 não tem vida social. O trabalho é muito puxado... vem muito, muito, muito tipo de gente, até por ser um centro de vendas. Então saí daqui muito estressada... - LojistaVendedora de Galeria.

Ainda que haja um modelo escópico e geral de como deve ser uma cidade, o movimento das ruas o transcende. Soares (2014, p.175) colabora ao salientar que "ler a escrita da cidade e a cidade como escrita é buscar o legível num jogo aberto e sem solução". Na interpretação da tessitura (i)legível, o devir dos significantes proporciona uma possibilidade de desvelamento de grafias variadas no cotidiano. As sociabilidades são mais legíveis quando, entre os discursos dos distintos tipos sociais evidencia-se o sentido de "movimento" pela mensuração da "agitação" de "clientes", uma maneira de definir as expectativas comuns das práticas espaciais na centralidade.

As sobreposições de sociabilidades conduzem a práticas espaciais específicas. Como situa Souza (2013, p.241, grifos no original), "práticas espaciais são práticas sociais em que a espacialidade (a organização espacial, a territorialidade, a 'lugaridade'...) é um componente nítido e destacado da forma de organização, do meio de expressão e/ou dos objetivos a serem alcançados". Assim convergem na criação, na organização e na sistematização de modos de viver, perceber e transformar o espaço no lugar da vida cotidiana.

Por meio de expressões e de traços comuns das percepções sobre suas práticas espaciais, os tipos sociais na 'Rua 44' fornecem leituras próprias sobre suas trajetórias. As quais se revelam permeadas de cenários com traçados perenes (TELLES, 2006) e sinalizam para a formulação de discursos entrecruzados, que podem revelar o evidente e o oculto da vida cotidiana (PAIS, 2003). A "variedade" de roupas é percebida no senso comum como o elemento indutor subjetivo e objetivo das práticas espaciais pela 'Rua 44'.

A "agitação" de consumidores na centralidade se sustenta na representação de que os produtos lá vendidos são também confeccionados pelas próprias lojas e não apenas reproduzem cópias de marcas famosas ("pirataria"). Para os entrevistados essa característica diferencia a 'Rua 44' de centralidades similares no país, como a "25 de Março" em São Paulo e o "Saara" no Rio de Janeiro.

Aqui nós temos clientes do Maranhão, Pará, Mato Grosso, Rio de Janeiro, São Paulo. Aí eu falo gente, mas vocês vêm de São Paulo pra comprar aqui. Eles falam que aqui é melhor, tem mais variedade, aqui tem fabricação própria. Lá é muito fluxo de chinês, então fica tudo meio igual. Aqui não o pessoal gosta dos modelos, dos desenhos... Por isso eles vem pra cá, porque diz que a moda aqui é muito diversificada. Não posso dizer do Brasil todo, mas grande parte. Da Bahia também. Lojista-vendedora de Galeria

O melhor aqui são as roupas, porque...o preço e a qualidade das roupas...tem de tudo lá... muita variedade, diferente do que a gente vê no comércio em geral, em galeria e mesmo em shopping...variedade de tudo que é coisa. - Cliente (Belém) A Feira Hippie em si, até por ser a maior a céu aberto na América Latina, você encontra muita variedade, vai encontrar de tudo aqui. Agora também não é só a feira em si, mas a região, a 44, as proximidades, as lojas. - Feirante da Feira Hippie

No entanto, os personagens não percebem que a enorme variedade de modelos de roupas e assessórios seguem tendências globais ditadas pelo campo da moda. Esse campo é dominado por grifes, que exercem influência sobre as representações sociais dos 'gostos' de consumidores, profissionais e

$\begin{array}{llllll}\text { Caminhos de Geografia } \quad \text { Uberlândia - MG } & \text { v. 21, n. } 73 \quad \text { Mar/2020 } & \text { p. 458-476 Página } 461\end{array}$


trabalhadores da moda. Segundo Bourdieu (1983, p.215) "o que faz a magia da grife, é o conluio de todos os agentes do sistema de produção de bens sagrados. Conluio perfeitamente inconsciente, é claro". Invariavelmente são fomentados nexos de consumo centrados em mercadorias similares àquelas de classes mais abastadas.

A similaridade das mercadorias não é algo incidental, é parte do espetáculo do capitalismo na vida cotidiana. Como explica Debord (1997, p.23) "o que liga os espectadores é apenas uma ligação irreversível com o próprio centro que os mantém isolados. O espetáculo reúne o separado, mas o reúne como separado". Nesse sentido, o produto em um ambiente popular, como da 'Rua 44', não possui a mesma valorização e prestígio que à desfrutada por aqueles destinados aos grupos sociais com maior poder aquisitivo, a exemplo dos produtos encontrados em shopping centers.

A facilidade de acesso às réplicas mascara as desigualdades sociais entre "ambulantes", "feirantes", "vendedores", "lojistas" e os diversos "clientes". Como asseveram Lipovestsky e Serroy (2011, p.59), "afirmam-se ao mesmo tempo o princípio do pleno poder sobre a condução de si próprio e as manifestações de dependência e de impotência subjetivas". Ao mesmo tempo em que há uma 'independência' de escolha de qual produto comprar ou oferecer à venda, as pessoas tornam-se cada vez mais reificados em relação à espetacularização do consumo no cotidiano.

Lefebvre (1991, p.64) aponta que "a ideologia da produção e o sentido da atividade criadora se transformam em ideologia do consumo". Há a composição de um coletivo de situações e cenas cotidianas da 'Rua 44' que remetem à ideologia do consumo como fundamento da subjetividade dos personagens. Contudo, é importante compreender que "mesmo a mercadoria e o dinheiro, que reificam, não são inteiramente coisas, mas relações envolvidas no caminho das coisas" (LEFEBVRE, 1967, p.149). Ao transcender as mercadorias que conformam as práticas espetaculares e de consumo, existe uma dinâmica social muito diversificada no cotidiano, que revela as variadas práticas espaciais na centralidade.

Em meio ao espetáculo de mercadorias é observável o repertório performático dos diferentes personagens nas galerias e nas calçadas da 'Rua 44'. Cada vendedor - "ambulante" ou de galeria - adota uma estratégia para obter visibilidade em meio a uma infinidade de produtos similares. Truques que vão desde o desfile de modelos de lojas nos corredores abarrotados de galerias aos bordões gritados por "ambulantes" para atrair os passantes desatentos. O que não deixa de ser um contraste com a sensação de que na centralidade, como descreve Lopes (2014, p.36, grifos no original), "parece à mesma coisa, um Box igual ao outro, os produtos logo do lado são os mesmos, a mesma calcinha de algodão ou o short de tactel'.

Mais do que um todo espacial apenas composto pelo consumo das réplicas e pelas inculcações das ideologias do consumo, esse microcosmo da cidade é representado nas práticas dos seus tipos sociais pelo mundo do trabalho e do "empreender". Estar entre a posição de "trabalhador" e de "empreendedor" ganha feição ambígua nos discursos de "ambulantes", "vendedores", "feirantes", "sacoleiros" e "clientes", que conformam um devir que substancializa identidades sociais na reprodução das práticas espaciais na 'Rua 44'. Com essa ambiguidade é possível ler a tessitura das percepções no cotidiano de modo a revelar hierarquias e conflitos socioespaciais.

As percepções sobre o "empreender" direcionam representações negativas aos "ambulantes", especialmente por parte de "feirantes" e "lojistas". Esses criticam a venda de mercadorias nas ruas, prática considerada ilícita, e a criação de barreiras ao "fluxo" de "clientes" nas calçadas. Os "ambulantes" argumentam que também atraem "movimento" para a 'Rua 44' e buscam garantir o direito ao trabalho, particularmente porquanto afirmam que "lojistas" igualmente vendem mercadorias nas ruas. Os depoimentos elucidam entendimentos:

Aqui é muito bom pra fazer compras e vender. Mas quando tem os ambulantes atrapalha demais. Atrapalha o fluxo, pra andar, movimentar. - Vendedora de Galeria 2.

O povo compra lá na rua e não entra nas lojas... No dia que eles (ambulantes) não estão tem que ver o tanto que vende, vende demais. - Vendedora de Galeria 1 
No momento estou desempregado. Então estou aqui sobrevivendo, ganhando o pão de cada dia... Aqui vendo água, às vezes levo cliente nas lojas. Se o movimento tá fraco pra as lojas, vou vender água. Não espero. - Ambulante 1.

Os "ambulantes" são percebidos na condição de "ilegalidade". Na condição de 'presenças recusadas' sofrem com ordens excludentes no espaço, simplesmente por existirem na condição de grupo social (RIBEIRO, 2006). É exemplo o 'rapa', nome popular atribuído à ação (prática espacial) de fiscais e de guardas municipais para a remoção de vendedores irregulares, que causa "correria" corriqueira entre "ambulantes" do local.

Os feirantes da Feira Hippie por sua vez se autoproclamam como o núcleo da centralidade. Aqueles com a prática espacial mais decisiva para o "movimento" da 'Rua 44', que emerge especialmente ao "montar" a feira de sexta a domingo na Praça do Trabalhador. É comum "feirantes" e "clientes" descreverem a Feira Hippie como um lar de convivência amistosa, cuja memória e a longevidade da comunidade impulsionam a existência de um lugar de pertencimento. Tal percepção difere dos entendimentos de "clientes", "lojistas" e "vendedores", que enxergam suas práticas espaciais na 'Rua 44' principalmente associadas à compra e venda de mercadorias.

\begin{abstract}
Aqui pra gente, pra mim e pra muitos aqui, é mais um lar. Tem gente que fica bem aqui e não fica bem em casa... aqui é mais só que um lugar de trabalho. - Feirante da Feira Hippie.

Se for pensar, nós da Feira Hippie-Praça do Trabalhador alimentamos o Araguaia Shopping... durante a semana lá é morto... Aonde a Feira Hippie vai o povo vai, porque a Feira existe a mais de 40 anos... Lógico que vamos ficar aqui, mas se formos pra outro lugar, eu acredito que o povo ia junto com nós... Aqui a gente abrange tudo. Aqui tem de Panela a roupa... Até Campinas... porque quem compra direto tecido lá é a Feira Hippie. - Funcionária da Associação dos Feirantes da Feira Hippie.

Aqui pra gente é muito bom, porque a gente não fica limitada de trabalhar só daquilo ali... Aqui na 44 é igual uma empresa, quando você vê ela crescer, expandir, que tá dando tudo certo é muito bom! - Lojista-vendedora de Galeria.
\end{abstract}

Considerando conforme Kozel (2008) os mapas mentais como formas de linguagem é possível evidenciar diversos aspectos do cotidiano, que refletem as concepções do espaço percebido e vivido. $\mathrm{Na}$ composição de um mapa mental que sumariza a vivência naquela determinada espacialidade, os tipos sociais da 'Rua 44' salientam diferentes elementos em que convergem em suas práticas espaciais próprias.

Na construção de um desses mapeamentos, um "feirante" da Feira Hippie representou a 'Rua 44' com foco nas pessoas (Figura 2). Sua expressão cartográfica justificou-se na importância daqueles que efetivamente são responsáveis pela reprodução da centralidade. Em outro mapa, de uma funcionária da Associação dos Feirantes da Feira Hippie, a representação da 'Rua 44' dá destaque à feira em posição e dimensão - posicionou-a no centro do mapa (Figura 3).

Para um "ambulante" (Figura 4) as ruas são curvilíneas, como um desdobramento de sua mobilidade entre as galerias. Simultaneamente, esse sujeito cartografa pontos informais pelos nomes afetivos. O seu trajeto contido nas vias públicas indica como referenciais o "restaurante da irmã Neide", a "lanchonete Douglas", entre outros. Em contrapartida, o "movimento" sem fixações demarcadas é a referência para o mapa mental de uma "lojista" que passa poucas horas diárias na 'Rua 44' (Figura 5).

Como escreve Kozel $(2013$, p.64) "as pessoas constroem o sentido de espaço, não somente pela atividade consciente do pensamento teórico, mas, sobretudo pelo conhecimento intuitivo do espaço que passa a ser expresso". Por meio dos mapas mentais é possível evidenciar distinções entre as compreensões e os processos ativos de percepção socioespacial. Em outras palavras, na criação ilustrativa e gráfica de cartografar o espaço em que decorem seus cotidianos, os diferentes tipos sociais da 'Rua 44' evidenciam os modos pelos quais vivem e percebem a centralidade.

$\begin{array}{llllll}\text { Caminhos de Geografia } & \text { Uberlândia - MG } & \text { v. 21, n. } 73 & \text { Mar/2020 } & \text { p. 458-476 } & \text { Página } 463\end{array}$


Figura 2 - Mapa mental da 'Rua 44' realizado por um feirante da Feira Hippie.

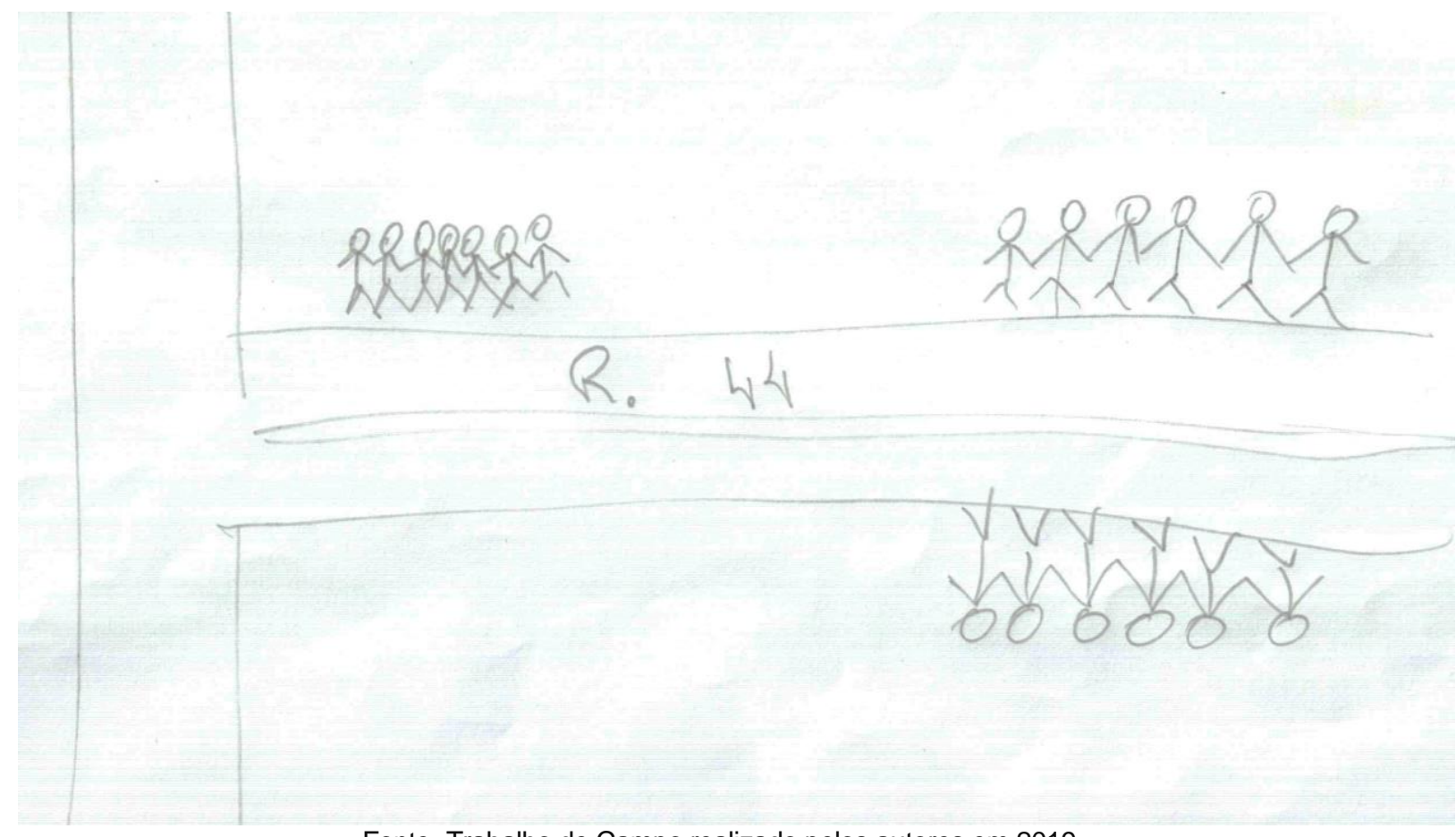

Fonte -Trabalho de Campo realizado pelos autores em 2019.

Figura 3 - Mapa mental 'Rua 44' realizado por funcionária da Associação da Feira Hippie.

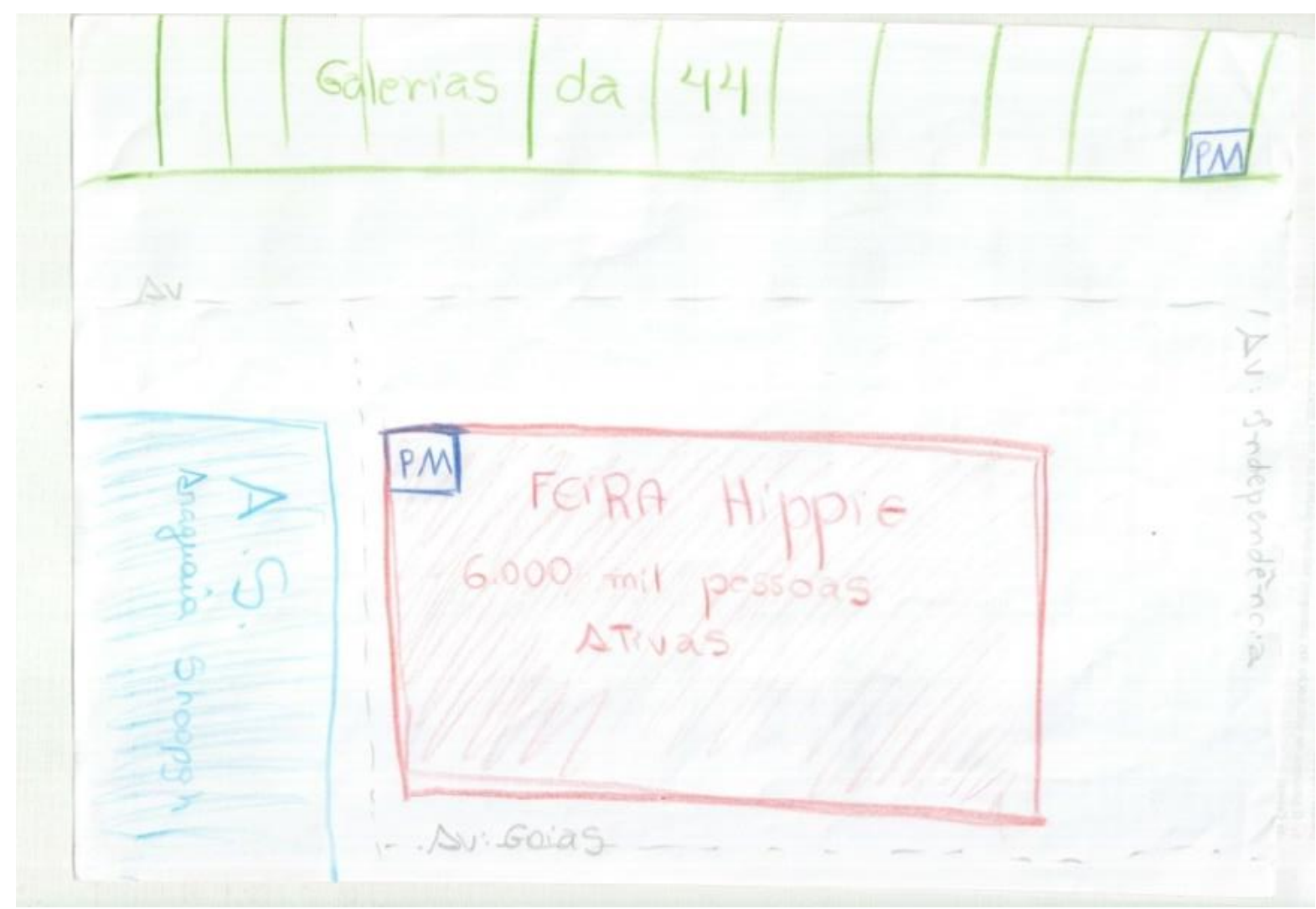

Fonte - Trabalho de Campo realizado pelos autores em 2019. 
Figura 4 - Mapa mental da 'Rua 44' realizado por um "ambulante”.

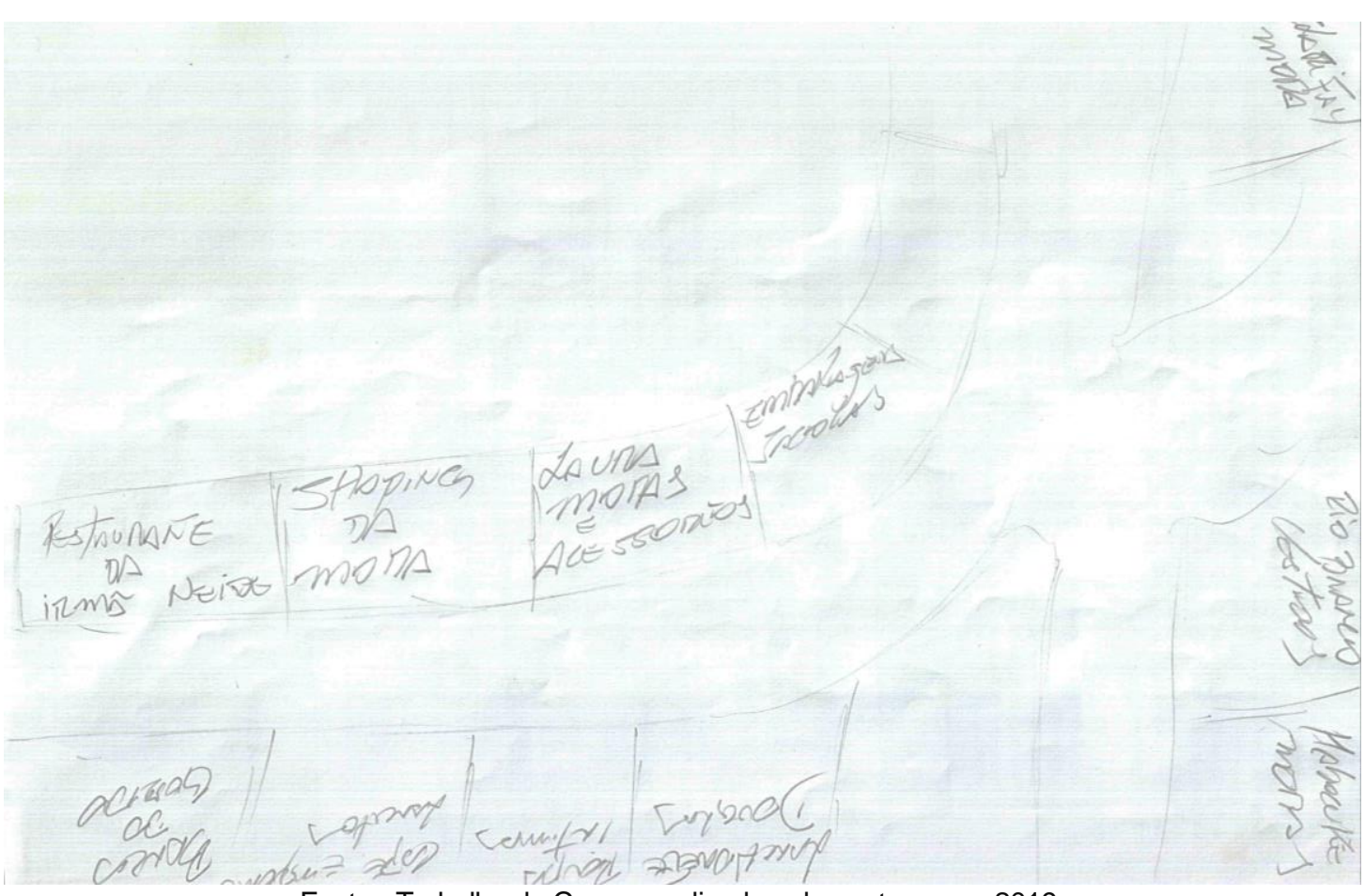

Fonte - Trabalho de Campo realizado pelos autores em 2019.

Figura 5 - Mapa mental da 'Rua 44' realizado por uma lojista de galeria.

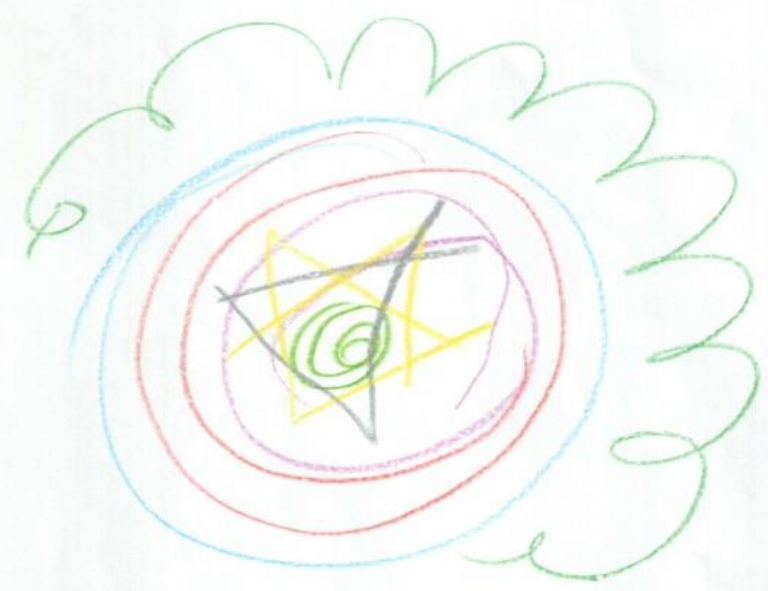

Fonte - Trabalho de campo realizado pelos autores em 2019.

De maneira geral, os mapas mentais demonstram que os distintos tipos sociais identificam recortes perceptivos traçados em função dos pontos de referência em seus deslocamentos. Como discorre Peixoto (2004, p.454), "a cidade é um espaço compartimentalizado pelo capital e pelo trabalho. Mas movimentos colocam continuamente em xeque essas repartições rígidas. Processos fluidos que vazam através dos limites...". Na espacialidade vivida existe, de fato, uma virtualidade potencial por onde as pessoas se associam e gestam arranjos, que também se materializam no todo que compõe a ordem do espaço concebido em formas práticas percebidas no cotidiano. 


\section{FORMAS ESPACIAIS E ESTRUTURAS SOCIAIS NA CENTRALIDADE DA 'RUA 44'}

Para aprofundar entendimentos sobre a produção da 'Rua 44' há a necessidade também da transcrição das formas espaciais. Segundo Santos (1985, p.49) "a sociedade só pode ser definida através do espaço, já que o espaço é o resultado da produção, uma decorrência de sua história, mais precisamente da história dos processos produtivos impostos ao espaço pela sociedade". Esses processos não estão determinados à priori, mas engendram forças sociais estruturadas em ação que moldam de acordo com intensões o espaço.

Em um labirinto de corredores, vielas, fachadas e marquises de lojas com painéis digitais e fotografias de manequins, as diversas formas espaciais da 'Rua 44' integram ruas, barracas e galerias em densidades e sobreposições. Esse cenário urbano em muito difere dos planos iniciais de Goiânia, em que esse espaço no Setor Norte-Ferroviário era concebido como limite a expansão urbana ao norte da cidade (GARBELIM, 2014).

A função contemporânea de centro do consumo popular de vestuário na 'Rua 44' começa-se a ser desenhada após 1995, quando ocorre a mudança da localidade da Feira Hippie - antes situada na Avenida Goiás. Cinco anos após a transferência da feira para o Setor Norte-Ferroviário surgiram as primeiras galerias nas proximidades. O presidente da Associação Empresarial da Região da 44 (AER44), um dos primeiros donos de galerias do local, revela que inicialmente muitas pessoas não acreditaram no potencial econômico da localidade:

[...] muitos me chamavam de doido, achavam que isso aqui não tinha solução, mas a transferência da Feira Hippie da Avenida Goiás para essa área, em 1995, foi o pontapé inicial para a transformação. - Presidente da AER44, entrevista extraída da reportagem de Lima (2019, p. 36).

Centralidades associadas aos ramos de vestuário em Goiânia são significantes antes mesmo da 'Rua 44'. Como a Avenida Bernardo Sayão, que segundo Lopes (2014) perdeu gradualmente sua posição de centro desde 2006, em sentido contrário à ascensão gradativa dos empreendimentos da 'Rua 44'. Esse movimento ocorre de modo mais incisivo na virada do século, com um número crescente de pequenos "empreendedores" interessados na localização da Rua 44 e adjacências, além de ser entroncamento de importantes avenidas, como a Av. Independência e a Av. Goiás.

A existência do Terminal Rodoviário de Goiânia-Araguaia Shopping é a principal vantagem da 'Rua 44' segundo os personagens, especialmente se comparada com demais locais similares em Goiânia e em Goiás. A mudança da rodoviária para esse terreno, em uma área no Setor Norte Ferroviário, ocorreu em 1987 com a promessa de facilitar o trânsito de ônibus e o acesso de viajantes. Em 2019, 32 anos depois, os congestionamentos são constantes no entorno em decorrência do incremento no fluxo da 'Rua 44'. O Terminal Rodoviário de Goiânia é amalgamado ao Shopping Araguaia, criado em 2001. O shopping na Rodoviária oferece praça de alimentação, supermercado, cinema, atendimento de órgãos estatais, lojas e estacionamento.

É salutar apreciar que, conforme estudo do Observatório do Turismo de Goiás (2019), nas imediações da 'Rua 44' está a maior oferta de leitos em hotéis ou pousadas entre as distintas centralidades de Goiânia. Também empresas de turismo e de transporte interestadual de encomendas, que já se alocavam nas imediações do Terminal Rodoviário, foram impulsionadas e promovem uma circulação constante de ônibus proveniente do interior de Goiás e de Estados como Bahia, Maranhão, Mato Grosso, Pará, Piauí, Tocantins, e demais do Centro-Oeste, Norte e Nordeste, do interior de São Paulo e de Minas Gerais.

Por essa vasta gama de serviços e acessos ao entorno, a centralidade da 'Rua 44' conforma-se progressivamente como um 'novo centro' em Goiânia, com capacidade de reunir coisas e pessoas de distintos locais do país. As formas espaciais mais evidentes confluem a esse cenário. Mas ao observar mais atentamente os desenhos e os equipamentos urbanos constata-se que as formas espaciais também revelam temporalidades distantes.

$\mathrm{Na}$ 'Rua 44' resistem permanências no espaço de marcadores atinentes a usos sociais concebidos para tempos remotos. Como os antigos galpões industriais que vão sendo re-funcionalizados em galerias. As moradias populares que dão terreno a novos hotéis. Atividades diversas antes prestigiadas que deixam de serem relevantes.

Como indicado na Figura 1, nas imediações da Rua 44 lista-se diversos serviços públicos de assistência social, como o Centro de Convivência de Idosos do Norte-Ferroviário, o Centro de Referência em Saúde do Trabalhador, o Centro de Valorização da Mulher e o Distrito Sanitário do SUS, além dos nomes "Praça

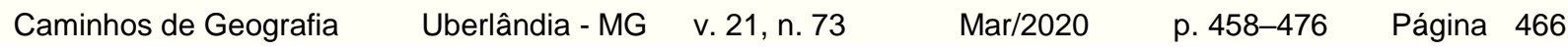


do Trabalhador" e as casas da antiga "Vila Operária". Tais elementos são reminiscências das necessidades associadas à ocupação de trabalhadores humildes nas bordas da antiga Estação Ferroviária de Goiânia, entre os 1950 até a década de 1970.

Em detrimento dos serviços necessários para organização da reprodução da 'Rua 44' nos anos 20002010, essa estrutura revela as ocupações populares dos que ali viveram e desenharam o seu pedaço de cidade no correr do tempo. Na transformação das espacialidades "é o tempo que baliza a sucessão das formas, suas conexões" (LEFEBVRE, 1967, p.374). As funcionalizações e re-funcionalizações dos usos de um determinado espaço não são instantâneas, implicam em um processo que deixa rugosidades, como denomina Santos (1985). As rugosidades permanecem visíveis e indicam no espaço relações sociais que nem sempre estão transparentes no presente.

Assim como Santos (1985), para Soja $(1989$, p.129) a produção da espacialidade capitalista "is no onceand-for-all event. The spatial matrix must constantly be reinforced and, when necessary restructured - that is, spatiality must be socially reproduced, and this reproduction process is a continuing source of conflict and crisis". Esse processo constante de reformulações implica no devir das formas urbanas, que marca a efemeridade de espaços produzidos no âmbito da organização social do capitalismo. No Setor NorteFerroviário, o processo de reprodução do centro de atacado e varejo nasce na convergência de processos históricos que alteraram a matriz espacial de outrora.

Desse modo, é possível identificar que as formas espaciais expressam às intencionalidades, os planos e os sentidos quanto à organização das coisas, pessoas e fenômenos que se distribuem de modo ordenado no espaço pelo tempo. Gomes (2009, p. 25) salienta que "há, coerências, lógicas, razões que presidem essa distribuição.". O ordenamento das formas espaciais torna-se objeto e fenômeno essencial ao revelar os fixos estruturantes e estruturados por temporalidades difusas, ainda que não permita a identificação imediata das forças sociais estruturantes atuantes na produção do espaço no presente.

Na perspectiva das ações estruturadas é necessário conhecer a atuação dos poderes que possibilitam a organização das formas espaciais, como sujeitos ativos da organização dos fixos na centralidade da 'Rua 44'. A organização das formas espaciais é definida por níveis, ao qual Carlos (2011) caracteriza como econômico, político e social. O nível econômico permite a reprodução do capital, o político são as estratégias que visam à hegemonia espacial, e o social é o nível em que esses processos anteriores se desenrolam na dinâmica da vida cotidiana (CARLOS, 2011). Como condição da produção do espaço, as ações dos sujeitos sociais articulam esses níveis em campos estruturados próprios e interconectados na vida cotidiana.

O centro comercial da 'Rua 44', em nível econômico, abrange 150 mil empregos diretos e receita média de $\mathrm{R} \$ 570$ milhões por mês. Movimenta anualmente quase $\mathrm{R} \$ 7$ bilhões. Caso fosse um ente federado municipal, possuiria o quinto maior Produto Interno Bruto (PIB) entre as 246 municipalidades do Estado de Goiás (LIMA, 2019). Inclusive estaria à frente de munícipios como Catalão ( $R \$ 5,6$ bilhões), Itumbiara $(R \$$ 3,9 bilhões) e Jataí ( $R \$ 3,8$ bilhões). Cidades com significativa presença do agronegócio e de atividades assessórias, além de indústrias automobilísticas e um importante setor de serviços públicos ou privados.

As projeções dos sujeitos econômicos não reconhecem ou preveem crise para a 'Rua 44'. A construção de novos empreendimentos e a refuncionalização de galpões são uma constante. No início de 2019 , segundo a AER44, eram mais de 13 mil pontos de venda, com previsão que ao final do ano alcance um valor total superior a 15 mil, espaçados em 97 galerias e shoppings populares (MONTEIRO, 2019). Se consideradas as 6 mil barracas da Feira Hippie, as 600 da Feira da Madrugada, as lojas de rua e do Araguaia Shopping, os milhares de "ambulantes", não menos de 25 mil pontos de vendas estão na 'Rua 44'. Reportagens exaltam a centralidade em Goiânia como o segundo maior "polo de moda" do país, somente atrás do Brás em São Paulo, e a Feira Hippie como a maior feira a céu aberto da América Latina (MARZANO, 2018; MARINA, 2019).

Além dos interesses no nível econômico, para compreender as estruturas sociais atuantes na produção da centralidade da 'Rua 44' é preciso perceber como poderes políticos formulam estratégias para esse espaço, especialmente no que concernem às decisões institucionais. Os interesses, motivações e vontades econômicas somadas às ações políticas definem as concepções do arranjo espacial, que não é etéreo e vazio, mas concebido por decisões estruturantes.

$\begin{array}{llllll}\text { Caminhos de Geografia } & \text { Uberlândia - MG } & \text { v. 21, n. } 73 & \text { Mar/2020 } & \text { p. 458-476 } & \text { Página } 467\end{array}$


No âmbito político da sociedade civil os posicionamentos se expressam em distintos momentos ou intensidades por meio de representações coletivas. Entre os sujeitos que organizam essas representações, a Associação dos Feirantes da Feira Hippie, a Associação Empresarial da Região da 44, a Associação dos Ambulantes da 44 - Feira da Madrugada e a Associação Montadores de Barracas são os que mais incidem influência na 'Rua 44'. Esses coletivos representam anseios dos sujeitos interessados no comércio popular, mas não se comportam como uma categoria social, antes representam tensões e convergências cotidianas sobre os sentidos de "popular" na 'Rua 44'.

Em meio aos interesses organizados no âmbito da sociedade civil desponta uma enormidade de ações dos poderes de Estado, que se apresentam contumazes na 'Rua 44'. Como a constante ação da Guarda Civil Metropolitana, da Secretaria Municipal de Fiscalização, da Secretaria de Infraestrutura e Serviços Públicos, da Secretaria de Planejamento e Habitação, da Secretária Municipal de Indústria, Comércio, Trabalho e Serviços (Semic), da Agência Municipal de Turismo e da Goiás Turismo (agência estadual). Cada uma dessas instâncias institucionais de atuação de Estado regula e controla as ações dos tipos sociais e das práticas espaciais cotidianas.

Ao mesmo tempo em que atuam politicamente, os sujeitos de sociedade civil e de Estado se defrontam com poderes influentes de mercado no cotidiano. Os principais agentes de mercado são os shoppings Mega Moda, que no dito dos entrevistados pertence ao grupo varejista 'Novo Mundo', e Gallo, de incorporadores ligados à montadora de tratores 'Planalto'. Os sujeitos de mercado são percebidos como "empresários" ou "grandes" por "lojistas", "feirantes", "ambulantes" e "consumidores", já que possuem "funcionários" e articulações nas distintas estruturas de poder.

Nesse sentido, o mapeamento de uma vendedora de galeria destacou os elementos estruturantes que formam o aglomerado do centro comercial (Figura 6). A Rodoviária ocupa espaço central do mapa por onde os outros locais são agregados. Ainda que a autora do mapa não trabalhe em nenhuma das três galerias, Mega Moda, Mega Park e o Shopping Gallo (em construção) são destacados como referências da centralidade em seu mapa mental. Representação similar também é vista no mapa mental desenhado por outra vendedora de galeria (Figura 7). Infere-se que esses pontos podem significar locais de oferta de trabalho mais abundante e de trabalho mais prestigiosos para vendedores.

Figura 6 - Mapa mental da 'Rua 44' realizado por uma vendedora de galeria.

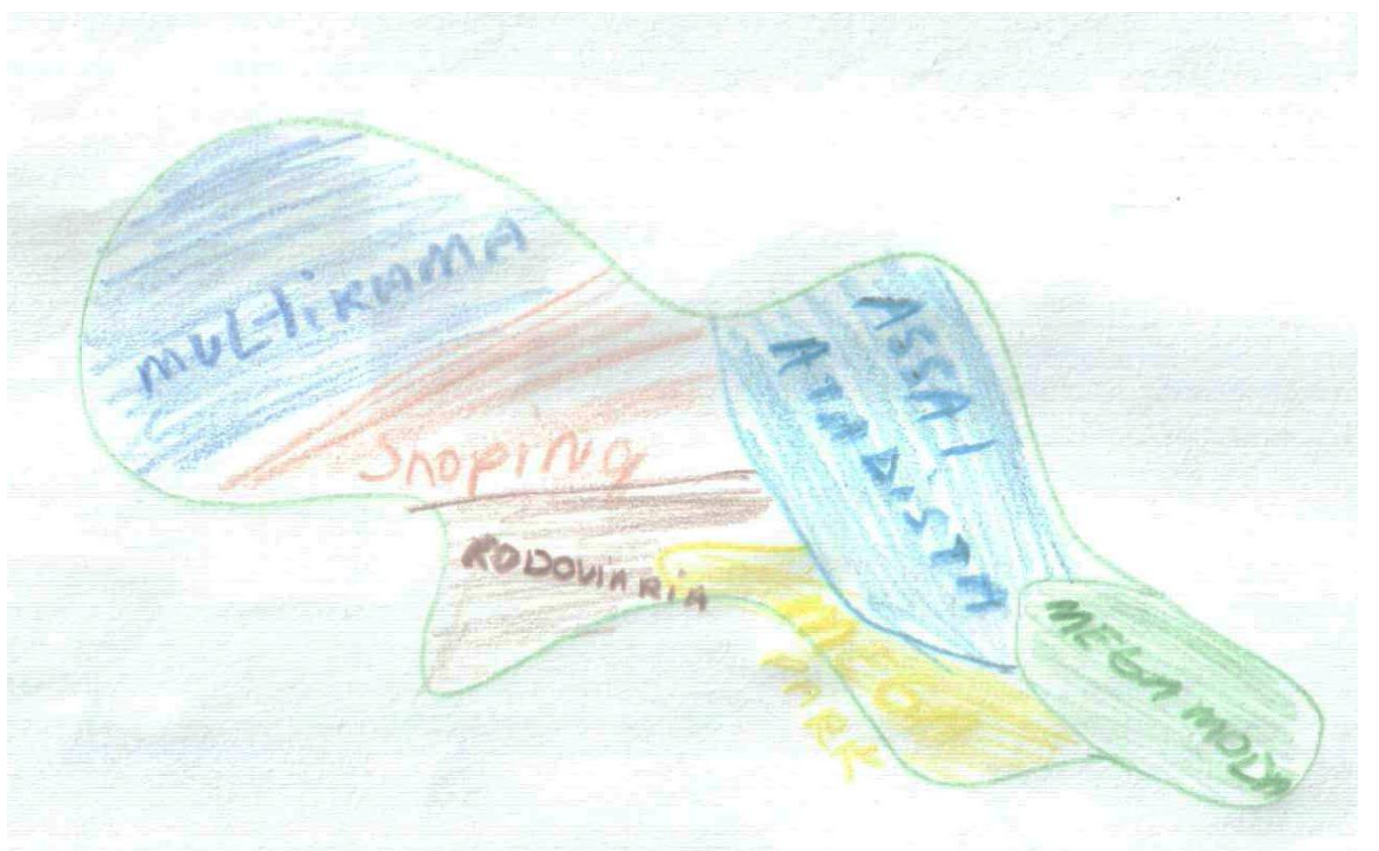

Fonte - Trabalho de Campo realizado pelos autores em 2019. 
Figura 7 - Mapa mental da 'Rua 44' realizado por uma vendedora de galeria.

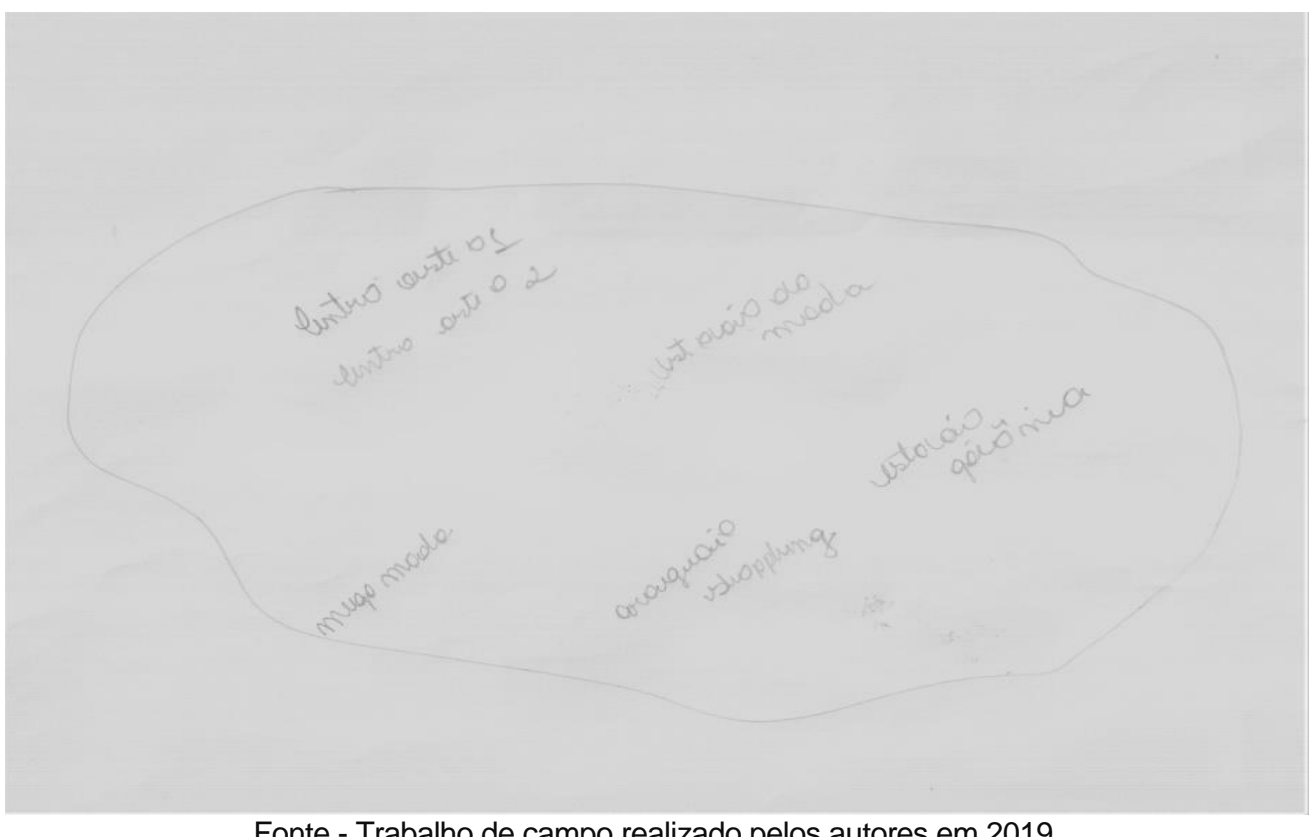

Fonte - Trabalho de campo realizado pelos autores em 2019.

O ordenamento espacial da 'Rua 44' ora revela contradições nos pontos de vistas e interesses, ora é evidenciada a conexão das estruturas do poder público com anseios específicos dos sujeitos da centralidade. Na busca pela reprodução social na centralidade, os múltiplos grupos políticos e econômicos almejam projetar vontades para desenhar as formas espaciais vividas no cotidiano.

\section{ARENA DE CONFLITOS POLÍTICOS NA 'RUA 44'}

A multiplicidade de sujeitos que representam interesses na produção da centralidade da 'Rua 44' expressam sobreposições de tensões no que tange as práticas espaciais, que também desencadeiam conflitos sociais. A extensão dos conflitos envolve desde "ambulantes" aos "lojistas" e "feirantes". Carlos (2011) entende que no nível social observar os conflitos é necessário para compreender as ações e as percepções dos sujeitos do, no e para o espaço.

Para decifrar o nexo de práticas e ordenamentos socioespaciais com os conflitos decorrentes é preciso entender o espaço concebido por grupos hegemônicos em relação à dinâmica social da vida cotidiana. De acordo com Silva (2018, p.438) "o espaço não é espontâneo; ele é produto e decorre da performance da sociedade organizada em grupo, conduzido pela lógica da produção e reprodução da vida". Logo, é nesse contexto que a conflitualidade pode ser desvelada como sinal de anseios de sujeitos diversos em ação.

Um momento especial de observação da ação dos sujeitos na produção social da centralidade da 'Rua 44' foi à movimentação política entre 2018 e 2019, que teve como ebulição os transtornos ocasionados no curso de algumas obras públicas. Entre essas, as principais são as ações preservacionistas na Estação Ferroviária, a adequação das vias públicas ao novo trecho do Bus Rapid Transit (BRT) Norte-Sul e a reforma da Praça do Trabalhador - Local da Feira Hippie nas quintas, sextas, sábados e domingos. Em especial, o projeto "Reurbanização da Praça do Trabalhador" revela momento que se instaura uma arena política de conflitos na 'Rua 44'.

Em novembro de 2018, a AER44, a Associação dos Feirantes da Feira Hippie e outros apoiadores se reuniram com a Prefeitura de Goiânia para discutir a reforma da Praça do Trabalhador. O debate centrou na acomodação de feirantes durante as obras. Os representantes da Prefeitura desde então asseguraram ter realizado mais de 20 reuniões (MARQUES, 2019). Entretanto, os tipos sociais da 'Rua 44' expressam entendimentos de que a falta de "comunicação", "diálogo", "participação" e "união" das partes foi fundamental para o acirramento dos conflitos, especialmente entre agentes públicos, "feirantes" e "ambulantes". 
Vejo vários lados. Os ambulantes que estavam irregulares. O feirante que pagam caro para estar aqui e não querem tomar prejuízo. Vejo o lado da prefeitura, dos governantes também. Mas faltou muito comunicação, tanto interna, quanto com a mídia externa... Faltou aquele amparo da Prefeitura, essa organização também é a responsabilidade deles. - Feirante da Feira Hippie.

o Prefeito anunciou que ia fazer reformas drásticas... deu um prazo tal e falou que ia chamar já pra falar como seria. Isso ele falou na primeira reunião... - Funcionária da Associação dos Feirantes da Feira Hippie.

Acho um negócio desnecessário, porque poderia haver união, um diálogo. Ver o que é melhor. Já que o prefeito quer tirar daqui, ele tinha que ter um lugar pra colocar a gente... Mas eles só querem tirar. - Ambulante 1.

Em razão de desacordos sobre a alocação temporária de feirantes e ambulantes durante a reforma, no mês de junho de 2019 ocorreram seguidos protestos na 'Rua 44'. Em 10 de junho houve um protesto organizado pela Associação dos Feirantes da Feira Hippie que agrupou aproximadamente 800 associados e parceiros. O ato reivindicava soluções dos impasses para a montagem das barracas no curso da reforma, com a posterior realização de uma reunião de representantes de "feirantes" e da Prefeitura. $\mathrm{Na}$ manifestação foi possível observar que, entre uma cena e outra do protesto os sujeitos entoavam orações cristãs-religiosas.

Já no dia 13 de junho, "ambulantes" também organizaram um protesto. Reportagens relatam a presença de 500 pessoas, as quais fecharam parte da 'Rua 44' (O POPULAR, 2019). Os presentes discursavam inconformados com a decisão de que nos sete meses previstos para a reforma, os pontos por eles ocupados seriam destinados a abrigar as barracas da Feira Hippie.

Para além dos desencadeamentos políticos-institucionais, com desdobramentos em mais reuniões e protestos com representantes do Poder Público ao longo de 2019, cabe registar as percepções dos sujeitos ante os acontecimentos. $\mathrm{Na}$ arena de conflito, "lojistas", "vendedores" e "feirantes" afirmam-se como vítimas de "políticos" e, ao mesmo tempo, deslegitimam "ambulantes". Os "ambulantes" projetam ocupar o espaço para "trabalhar" e aceitam horários alternativos. Os outros personagens dizem temer ações violentas de retaliação dos vendedores informais. Elemento que reforça a percepção negativa sobre os denominados "ambulantes".

A vivência etnográfica e durante as derivas urbanas evidenciou nítidas tensões entre as partes envolvidas no conflito, que era constatada pela presença permanente de viaturas da Polícia Militar e da Guarda Metropolitana. essas forças policiais se demonstravam a postos para vigiar barracas da Feira Hippie ou portas das galerias. Os discursos dos sujeitos conferem interpretações dos protestos,

O primeiro protesto foi o da Feira Hippie, eles fizeram um ato, inclusive agora já tem lugar certinho pra eles. Os camelos estão reivindicando trabalhar nas madrugas, era assim antes, mas não tinha fiscalização... o problema deles é que atrapalham essa questão do fluxo... Aí foi passando, foi afrouxando... Agora pra tira de vez, a polícia tem que estar aqui... A Feira da Madruga já monta de quarta pra quinta e de quinta pra sexta. Na sexta, a Feira Hippie monta, sendo que antes era só domingo. Aí reivindicaram e ganharam o sábado. Agora acharam que tava pouco. Aí reivindicaram e ganharam a sexta. O público para esse tanto de gente é pouco... Lojista-vendedora de Galeria.

Nossos protestos são na Praça do Trabalhador e dentro dessa área. Sempre são aqui e sempre são de paz. Nunca teve violência. Quando tem protesto na 44, eu não vou, porque sou medrosa. Mesmo sendo funcionária da associação não vou, porque dizem que são protestos bem violentos... Eles também foram bem violentos pra falar contra a Feira Hippie... gerou tipo uma guerra, os ambulantes da 44 e os feirantes da Feira Hippie. Mas nunca partiu da Feira, é que eles acham que foi a Feira Hippie que tá tirando eles de lá, sendo que isso veio do Prefeito. - Funcionária da Associação dos Feirantes da Feira Hippie

Tem que gerar uma solução, porque do jeito que tá vai gerar mais conflito. Porque quando tem desentendimento de uma das partes tem a explosão, aí tem que por polícia, tropa de choque. Porque o povo não vai sair, aqui é a fonte de dinheiro da cidade... aqui é um polo industrial, gira muito dinheiro... - Ambulante 1.

O espaço percebido como conflituoso estimula os sujeitos a friccionarem percepções sensitivas, sentidos e sentimentos para legitimar suas ações sociais. Os sentimentos influenciam nas percepções sensíveis da ação social, pois estão no limiar entre a ação reflexiva e a ação inconsciente (LOPES, 2017). As

$\begin{array}{lllll}\text { Caminhos de Geografia } \quad \text { Uberlândia - MG } & \text { v. 21, n. } 73 \quad \text { Mar/2020 } & \text { p. 458-476 Página } 470\end{array}$


percepções também implicam na multiplicidade de sentidos, convergentes ou divergentes. Weber (2006) considera fundamental compreender o sentido que os sujeitos dão às ações para si e em relação aos outros, como conferem significação aos códigos, aos conhecimentos e as linguagens, de modo a legitimar condutas, ideias e valores.

Com a reforma na Praça do Trabalhador, o sentimento de "medo" é o sentido principal de distintos personagens se engajarem e legitimarem os protestos diante das incertezas com o futuro. Se "perder espaço relaciona-se à própria sobrevivência da pessoa ou do grupo" (SILVA, 1986, p.141), a possibilidade de perca desse local para aqueles que dele dependem, sejam "feirantes" ou "ambulantes" implica na incerteza quanto à reprodução da vida. Os seguintes trechos indicam esses sentimentos,

Eu estou com medo! No meio desses camelôs existem várias pessoas negativas, que gostam de vandalismo... Então eu tenho medo! Eu tenho medo, porque a polícia não está pra brincadeira... Teve até um líder deles que disse que se eles trabalharem vão quebrar as lojas... O que a gente tem haver?... Então espero que no futuro a gente esteja mais organizado, melhor para os clientes locomover, espero ver essa praça muito bonita... a Feira Hippie organizada, a 44 limpa... - Lojistavendedora de Galeria

os ambulantes da 44 tão chateado com a Feira Hippie, a gente tem medo até de guerra aqui na 44... sexta, sábado e domingo vai ficar tenso... sendo que foi projeto do Prefeito... porque prejudica a galeria e de alguma forma a Feira Hippie, prejudica o trânsito... Até porque, a gente tem medo de quando acabar a revitalização... A gente não tem certeza que vai voltar. Muitos feirantes com medo... Eu acho que vai ter um pouco de transtorno no início, mas depois vai ser melhor. - Funcionária da Associação dos Feirantes da Feira Hippie

Tem gente de todo lugar que vem pra cá, mas acho que não vai melhorar, acho que a tendência é piorar. A tendência é cada vez mais fechar esse espaço... Ambulante 1

Espero que lá cresça cada vez mais, que as roupas fiquem mais barato, tenha mais diversidade, que as pessoas possam ter mais oportunidade de trabalhar... - Cliente (Belém).

O medo que delineia as percepções e as ações dos personagens pode ser identificado no mapa mental da funcionária da associação de feirantes (Figura 3), em que duas bases da Polícia Militar são cartograficamente representadas. Há uma percepção de ameaça que justificaria vigilância ostensiva.

Apesar do medo como sentimento comum, os sujeitos da 'Rua 44', como evidenciado na Figura 8, de alguma maneira também buscam possibilidades de desconstrução das geografias injustas. Em acordo com Soja (2014, p.57), entende-se que "todos los que están oprimidos, subyugados o explotados económicamente están sufriendo hasta cierto punto los efectos de geografías injustas". Assim, ao mesmo tempo, de modo residual emergem sentimentos de esperanças de que irão ocorrer melhorias na infraestrutura urbana, para que seja incrementado o movimento de clientes. Emergem nesse momento sugestões de alterações no arranjo espacial na 'Rua 44', em que são reveladas diferentes possibilidades de intervenção para melhorar a vida na centralidade.

Os sujeitos dão sentido e agem no espaço por meio das relações sociais concretas espacialmente situadas e efetivadas. Ocorre que, conforme ressalta Turra Neto (2015, p.54), "os hábitos, tradições, consensos, as práticas cotidianas pré-reflexivas cimentam espaços de relações que tendem a reforçar tanto a materialidade, quanto as relações, conexões e desconexões que as ações desencadeiam". As práticas sociais, portanto, convergem na tentativa de solução política de problemas espaciais efetivos da vida cotidiana. Assim, cada sujeito, com seu modo de viver e de perceber intensões concretas, projeta mudanças do ordenamento em curso na 'Rua 44'.

Se, como influi Souza (2013, p.244), "a ação social sempre é voltada, de acordo com Weber, para outros indivíduos, seja direta ou indiretamente" é visível à maneira pela qual os diferentes grupos conformam ações para validar sua existência. Com as manifestações políticas são criadas maneiras de enfrentar as adversidades da vida cotidiana e propor soluções para as disputas pelos espaços. Como visto no mapa mental de uma lojista-vendedora, ao projetar uma ideia de fechamento de vias laterais à Rua 44 para veículos, com a expectativa de criação de ruas exclusivas para pedestres (Figura 8). 
Figura 8 - Mapa mental da 'Rua 44' realizado por uma lojista-vendedora de galeria.

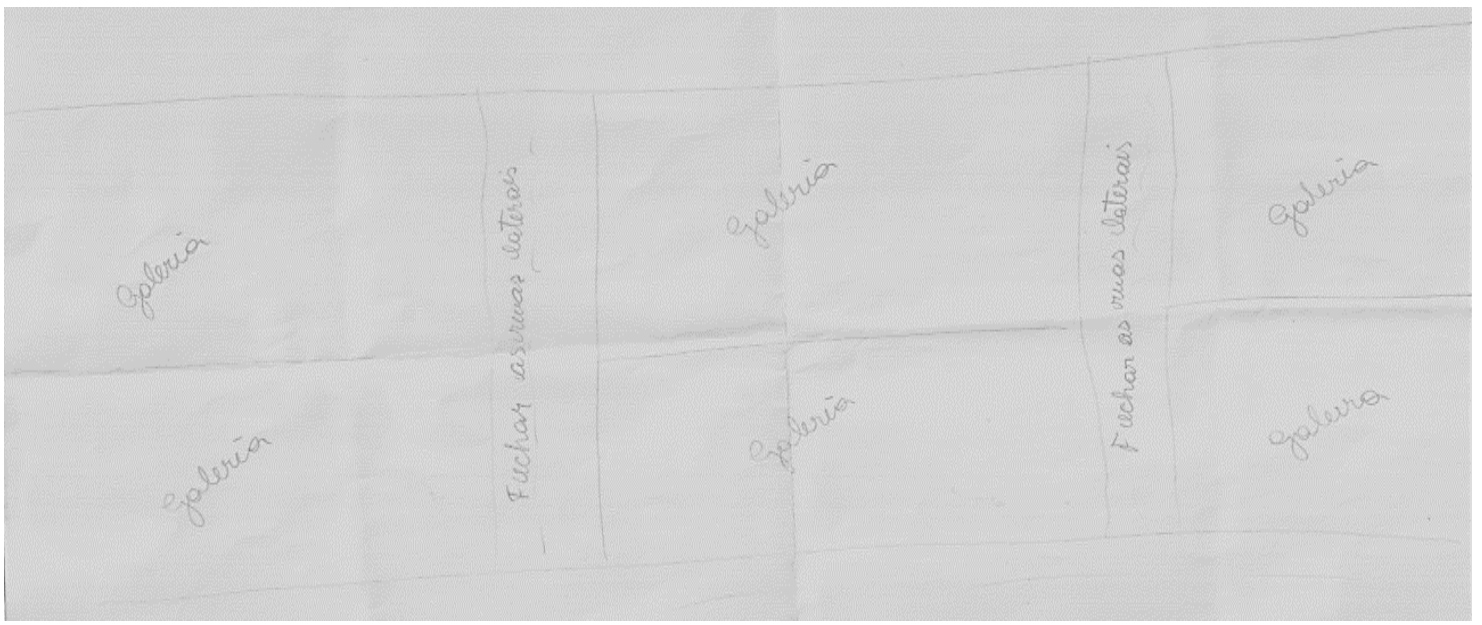

Fonte - Trabalho de campo realizado pelos autores em 2019.

Os sujeitos sociais criam elos políticos que permitem modos de impor algum tipo de prioridade ao ordenamento espacial de acordo com suas práticas e não somente reafirmar o concebido pelo poder de Estado. Como pondera Alvarez (2013, p.118), "o uso na/da cidade guarda a dimensão do viver, das práticas, das possibilidades de sociabilidade, de apropriação coletiva de espaços, da possibilidade de politização, da criação, da negação". O que implica na construção de solidariedade de distintos sujeitos sociais a fim de assegurar a reprodução de suas práticas espaciais.

Os múltiplos personagens da 'Rua 44', ainda que não livres de divergências, com base nos sentidos partilhados na vida social, sobre si e sobre os outros, fundamentam as solidariedades com base em três valores principais, a casa, a família e a religião. Essa tríade revela uma moral afeita a vínculos circunscritos ao mundo íntimo, que projetam refúgio na vida privada ou na utopia da "comunidade homogênea". Os discursos são elucidativos dos sentidos dessa cosmovisão,

Sou mãe de duas filhas, sou casada. Fora daqui sou dona de casa, sou crente, vou na Igreja, faço parte de um coral...toda quinta, eu e meus irmãos fazemos um jantar, porque eu sou muito família sabe? - Funcionária da Associação dos Feirantes da Feira Hippie

A maioria está aqui porque é uma potência... tem espaço pra todo mundo que quer empreender... Aqui trás o sustento, meu e da minha família. Eu sou casada, to grávida e tenho minha mãe comigo. Sou ativista social... sou religiosa do candomblé. A comunidade me motiva muito, meu pertencimento étnico, minha identidade. Lojista.

Eu faço parte da Igreja Universal. Sou evangélico... lá eu faço parte da UNP, é Universal nos Presídios... vou levar uma palavra de fé... porque o que mais me motiva é minha salvação, o que priorizo, mais que meu casamento, minha salvação. - Ambulante 1

Toda a luta, toda a guerra, é pelas minhas filhas. Tudo que faço. A vida que levo. Se não fosse elas, eu acho que levaria uma vida muito diferente. - Feirante da Feira Hippie.

A cosmovisão é o quadro de referência moral, que guia a compreensão das pessoas a fim de estabelecer uma versão dos acontecimentos frente às versões concorrentes (MESSENBERG, 2017). A cosmovisão forja um campo metapolítico de sentidos que permeiam as percepções culturais sobre a vida (PIERUCCI, 1990). A formação dessa cosmovisão por aqueles que atuam na 'Rua 44' e que é partilhada nas rotinas elevadas de trabalho em empresas familiares, sendo que a "casa" é ao mesmo tempo núcleo da sociabilidade e da solidariedade entre a família, o trabalho e as possibilidades de perceber o mundo.

Tal percepção reafirma posição que busca distanciamento dos temas públicos de interesse da sociedade. Nesse sentido, os personagens da 'Rua 44' avaliam a realidade sociopolítica em termos de insatisfação com o espaço público, mas com pouca motivação para expressar argumentações mais elaboradas sobre

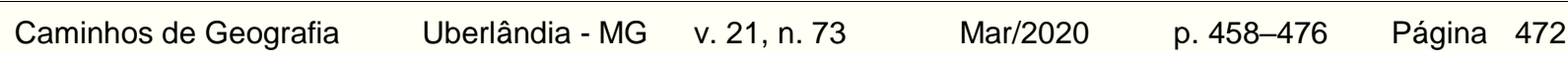


os contextos sociais que geram essas insatisfações. As insatisfações são justificadas genericamente pelas precariedades provocadas pela "corrupção" dos "políticos".

Tudo ladrão... os governos nesse Brasil não funcionam. No Brasil tem que mudar, tem muito roubo e não tão nem aí para os pobres. - Vendedora de Galeria 1

Corrupção! Mas corrupção não é o único problema, porque a corrupção sempre foi estrutural na política brasileira... não sei bem, mas acho que tem uma coisa da matança em série,... do empobrecimento pela questão da renda. - Lojista.

Corrupção geral aí... Já os governantes, a corrupção que tem, quando estão lá esquece o povo. - Ambulante 1

No senso comum, a corrupção difunde-se como produto da construção do pensamento social brasileiro, que entende a peculiaridade do país por meio das relações patrimonialistas entre Estado e sociedade. Essa visão é uma herança partilhada como mito entre os brasileiros. Tanto que ao analisar a cultura política nacional, Souza (2017) aponta que o discurso da 'corrupção' tende a demonizar o público e a escamotear ilicitudes privadas. Esse discurso também criminalizaria à priori a política e desviaria o foco das carências de cidadania para causas menores, como nos desmandos da Operação Lava-Jato (SOUZA, 2017).

Os discursos são moldados por representações de que "não presta" o "público" ou o "político" e é preciso "mudar tudo" ou "quebrar o sistema". A noção de "antissistema" na 'Rua 44' replica-se, entre distintos perfis ideológicos dos sujeitos, mas prevalecem naqueles autodeclarados "conservadores", "evangélicos" ou "empreendedores". Não mais precisos e menos genéricos são os discursos contrários a tais posições, mesmo entre os que se vêm como "ativistas" críticos ou "trabalhadores".

Acredito muito no Bolsonaro... Eu vejo que o Bolsonaro vai quebrar o sistema, como ele tá quebrando... Hoje ele faz coisa que um presidente não faz. Andar de moto numa capital... Antes era só aquela coisa de protocolo. Agora não, ele fala vou fazer do meu jeito, vou quebrar o protocolo, eu posso. - Lojista-vendedora de galeria. Já virou clichê, o tal do retrocesso... Mas tem alguns avanços micro que não vai da pra voltar atrás... acho que é isso, um avanço. - Lojista.

O Bolsonaro veio pra mostrar serviço, tá fazendo muita coisa... Mas ele tem que mudar muita coisa, o Brasil vive numa época de ditadura né. O mundo evolui e ele quer trazer uma era lá de trás... mas acho que ele é um cara sábio e vai melhorar... acho que tem a melhorar, porque saiu o PT... o maior problema é a corrupção. Ambulante 1.

Como as ações públicas e políticas-institucionais são generalizadas pela condição de "corruptas", as considerações sobre os sentido do espaço público se tornam previsíveis e tímidas pelos sujeitos políticos da 'Rua 44'. Mesmo as avaliações de governos sugerem pouco ânimo dos personagens, que com muito custo apontam a Prefeitura de Goiânia como principal e exclusiva responsável pela piora da cidade nos últimos anos e pelos transtornos existentes na 'Rua 44'. Todavia, poucos se sentem encorajados para analisar com mais detalhes os maiores problemas vividos e seus responsáveis tanto na cidade quanto na centralidade.

É uma bagunça, governo no Brasil é corrupção. - Vendedora de Galeria 1 Goiânia tá cada dia pior... tinha pessoas que vinha passar Natal e Ano Novo aqui só pra ver a iluminação. As praças eram perfeitas, agora não está mais assim... Há 10 anos atrás os postinho tinham dipirona, hoje não tem mais, porque vou no SUS... Acho que é o Governo Federal também, mas não sei... Tá tudo abandonado...Goiânia afundou, não sei se foi por causa do Marconi. - Funcionária da Associação dos Feirantes da Feira Hippie.

A má vontade com a política-institucional em um nível amplo também é expressão de uma cultura política historicamente construída com pouca possibilidade de abertura do Estado à participação da população nas decisões de interesse comum (AVRITZER, 2009). Tal elemento contribui para a desvalorização do espaço público e para a depreciação da ação política. O que justifica a necessidade pelos protagonistas da atuação direta através de seguidos protesto na 'Rua 44'.

Como espaço de produção da vida por meio dos conflitos e disputas, as ações pela preservação da lógica da centralidade da 'Rua 44' visam à criação de uma ordem que garanta sua continuidade. Silva (1986, p.142) entende que "a luta pela preservação do espaço de vida e do entorno começa, com o tempo, a

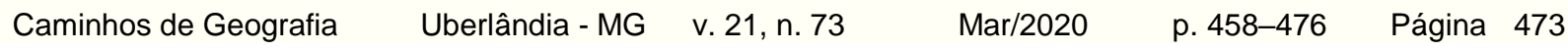


modificar as relações que definem o lugar". Essas lutas ocorrem nas convergências de usos e práticas que criam estratégias para lidar com os diferentes interesses que se opõem ao cotidiano social.

Por fim, o ordenamento e as práticas socioespaciais dos sujeitos sinalizam na estruturação de dinâmicas de produção de uma centralidade sobreposta e densa de sentidos sociais. Com base na atuação dos sujeitos é possível evidenciar as subjetividades. Como esses legitimam ações. Qual o espaço vivido, concebido e percebido mais do que simplesmente produto de e para o consumo. Mas também como uma arena política de conflitos como expressão do próprio sentido da vida dos tipos sociais e de suas práticas espaciais na centralidade da 'Rua 44'.

\section{CONSIDERAÇÕES FINAIS}

A centralidade da 'Rua 44' é produzida por tipos sociais, que são produto da ação de sujeitos articulados para a produção desse espaço e do próprio sentido de suas vidas. Na 'Rua 44', "feirantes", "ambulantes", "lojistas", "vendedores" e "clientes" definem trajetos em uma espacialidade percebida e definida pela intensidade do "movimento" de coisas e pessoas. A centralidade remete ao encontro entre esses tipos sociais e suas práticas espaciais correlatas.

Os tipos sociais próprios desse centro em formação se percebem e são percebidos como necessários à produção da vida cotidiana no, do e para 'Rua 44'. Ao passo que as relações reveladas na consubstanciação entre a materialidade e o sentido das ações sociais apontam para hierarquias e conflitos nas práticas espaciais dos sujeitos, que em devir reafirmam e transcendem a importância atribuída ao consumo em relação à vida social. Promovê-lo ou desfruta-lo une as ações dessa multiplicidade social em uma miríade de réplicas, repetições das coisas e das pessoas no espetáculo das mercadorias e do próprio espaço a ser consumido.

Como um centro popular destinado ao consumo, a 'Rua 44' apresenta formas espaciais em sobreposições densas e difusas, que são produto e elemento ativo da estruturação do espaço pelos sujeitos que atuam e concebem a produção da centralidade. O ordenamento das formas indicam desencontros na vida cotidiana, cujas tensões estimulam a atuação de sujeitos organizados e definidos pelas ações sociais. Em decorrência dessas ações surgem negociações e associações de "feirantes", de "ambulantes", de "lojistas", de "donos de galerias" e de "montadores de barracas". Também marcam posição a atuação intencionada de "empresários", fiscais, guardas, gestores públicos e políticos.

Essa diversidade apresenta e representa também interesses políticos nos momentos de conflitos socioespaciais. Momento em que também é instaurada uma arena política de conflitos na 'Rua 44', que por vezes extrapola as instâncias formais do poder e passa a abarcar as sociabilidades e sentimentos expressos na vida cotidiana dos tipos sociais.

Convergências podem revelar a solução dos problemas, porém podem acentuar divergências entre os protagonistas, que assim exigem engajamento em ações políticas. Insatisfações com as decisões institucionais na vida pública fazem emergir protestos e disputas sociais. É salutar, portanto, evidenciar que na vida cotidiana surgem maneiras de sobreviver, desafiar ou enfrentar os problemas de produção social do espaço, de reprodução da vida social e que colocam os desafios da construção do Direito à Cidade.

\section{REFERÊNCIAS}

ALVAREZ, I. P. A. A segregação como conteúdo da produção do espaço urbano. In: VASCONCELOS, P. A. (Org); CORRÊA, R. L. (Org.); PINTAUDI, S. M. (Org.). A cidade contemporânea: Segregação espacial. São Paulo: Contexto, 2013. p. 111-126.

ARRAIS, T. A. Seis modos de ver a cidade. Goiânia: Cânone Editorial, 2017, p.104-151.

AVRITZER, L. Sociedade civil e participação no Brasil democrático. Experiências nacionais de participação social. São Paulo: Cortez, 2009.

BOURDIEU, P. Questões de sociologia. Petrópolis: Ed. Vozes, 1983.

BOURDIEU, P. A miséria do mundo. Petrópolis: Ed. Vozes, 1999.

CARLOS, A. F. A. A condição espacial. São Paulo: Contexto, 2011.

$\begin{array}{llllll}\text { Caminhos de Geografia } & \text { Uberlândia - MG } & \text { v. 21, n. } 73 & \text { Mar/2020 } & \text { p. 458-476 } & \text { Página } 474\end{array}$


DEBORD, G. Théorie de la dérive. Internationale situationniste, n. 2, p.19-23, 1956.

DEBORD, G. A sociedade do espetáculo. Rio de Janeiro: Contraponto, 1997.

FLICK, Uwe. Introdução à pesquisa qualitativa. Tradução Joice Elias Costa. 3ª. ed. Porto Alegre: Artmed, 2009.

GARBELIM, M. S. A produção social do espaço na região norte de Goiânia: desconcentração, segregação e política urbana. Dissertação de Mestrado. Programa de Pós-Graduação em Ciências Sociais. Sistemas de biblioteca UFG, 2014.

GOMES, P. C. da C. Um lugar para a Geografia: Contra o simples, o banal e o doutrinário. In:

MENDONÇA, F. et all. Espaço e Tempo: Complexidade e desafios do pensar e fazer geográfico. Curitiba: Associação da defesa do Meio Ambiente e Desenvolvimento de Antonina (ADEMADAN), 2009. p. 13-30.

KOZEL, S. Representação e ensino: aguçando o olhar geográfico para aspectos didático-pedagógicos. In: SERPA, A. (Org.) Espaços culturais: vivências, imaginações e representações. Salvador: EDUFBA, 2008, p.71-90.

KOZEL, S. Comunicando e representando: mapas como construções socioespaciais. Geograficidade, v.3, n. especial, p.58-70, 2013. https://doi.org/10.22409/geograficidade2013.30.a12874

LEFEBVRE, H. Metafilosofia. Rio de Janeiro: Editora Civilização Brasileira, 1967.

LEFEBVRE, H. A vida cotidiana no mundo moderno. São Paulo: Editora Ática, 1991.

LEFEBVRE, H. A produção do espaço. Paris: Éditions Antrhopos, 2006.

LEFEBVRE, H. A Revolução Urbana. Belo Horizonte: Editora da UFMG, 2008.

LIMA, A. Aqui se faz a moda que seduz o Brasil. In: Goiás Industrial - Revista do Sistema Federação das Indústrias do Estado de Goiás. Goiânia-Go, ano. 67. №286. Fev 2019.

LIPOVESTSKY, G.; SERROY, J. A cultura-mundo: resposta a uma sociedade desorientada. São Paulo: Cia das Letras, 2011.

LOPES, H. P. Chafurdos na moda: Heróis e vilões na história das cópias. Goiânia: EdUFG, 2014.

LOPES, J. T. Razão, corpo e sentimento na teoria social contemporânea. Sociologia: Revista da Faculdade de Letras da Universidade do Porto, v. 12, n.1, 2017.

MAGNANI, José Guilherme Cantor. De perto e de dentro: notas para uma etnografia urbanaDe perto e de dentro: notas para uma etnografia urbana. Rev. bras. Ci. Soc. [online]. 2002, vol.17, n.49, pp.11-29.

https://doi.org/10.1590/S0102-69092002000200002

MARINA, A. Moda rentável. 2019. Disponível em:

<http://webcache.googleusercontent.com/search?q=cache:kOxa4ZQOVNOJ:impresso.em.com.br/app/noti cia/cadernos/cultura/2019/05/18/interna_cultura,251214/moda-rentavel.shtml+\&cd=2\&hl=pt-

BR\&ct=clnk\&gl=br>, acesso em 3 de julho de 2019.

MARQUES, D. Comerciantes e prefeitura entram em acordo para realocação da Feira Hippie. 2019. Disponível em: <https://newsgo.com.br/2019/06/10/comerciantes-e-prefeitura-entram-em-acordo-pararelocacao-da-feira-hippie/>, acesso em 3 de julho de 2019.

MARTINS, J. S. Henri Lefebvre e o retorno à dialética. São Paulo: Hucitec, 1996.

MARZANO, F. Além do sertanejo, Goiânia concentra o maior polo de moda do país. 2018. Disponível em:

$<$ https://www.correiobraziliense.com.br/app/noticia/turismo/2018/07/08/interna turismo,692863/comprasem-goiania.shtml>, acesso em 3 de julho de 2019.

MESSENBERG, D. A direita que saiu do armário: a cosmovisão dos formadores de opinião dos manifestantes de direita brasileiros. Sociedade e Estado, v. 32, n. 3, p. 621-647, 2017. https://doi.org/10.1590/s0102-69922017.3203004

MONTEIRO, L. Região da 44 segue em expansão. 2018. Disponível em: <https://www.opopular.com.br/noticias/economia/regi\%C3\%A3o-da-44-segue-em-expans\%C3\%A3o$1.1685158>$, acesso em 3 de julho de 2019. 
O POPULAR. Ambulantes da região da Rua 44 protestam em Goiânia. 2019. Disponível em: $<$ https://www.opopular.com.br/noticias/cidades/ambulantes-da-regi\%C3\%A3o-da-rua-44-protestam-emgoi\%C3\%A2nia-1.1820067>, acesso em 3 de julho de 2019.

OBSERVATÓRIO DO TURISMO DE GOIÁS Censo hoteleiro de Goiânia 2017-2018, Disponível em $<$ http://www.abihgo.org.br/sitewp/wp-content/uploads/2019/01/Censo-Hoteleiro-de-Goi\%C3\%A2nia-20172018.pdf>, acesso em 3 de julho de 2019.

PAIS, J. M. Vida Cotidiana: Enigmas e Revelações. São Paulo, Cortez Editora, 2003.

PEIXOTO, N. B. Paisagens Urbanas. São Paulo: Editora Senac São Paulo, 2004.

PIERUCCI, A. F. Ciladas da diferença. Tempo Social, v. 2, n. 2, p. 7-37, 1990. https://doi.org/10.1590/ts.v2i2.84798

RIBEIRO, A. C. T. Presenças recusadas: territórios populares em metrópoles brasileiras. Sociologia de capitais brasileiras: participação e planejamento urbano. Brasília: Líber Livro Editora, p. 11-33, 2006.

SANTOS, M. Espaço e Método. São Paulo: Nobel, 1985.

SILVA, A. C. De quem é o pedaço?: espaço e cultura. São Paulo: Hucitec, 1986.

SILVA, J. B. Geografia e movimentos sociais urbanos: novas abordagens. IN: SERPA, A.; CARLOS, A. F. A. (Orgs.) Geografia urbana: Desafios contemporâneos. Salvador: EDUFBA, 2018, p.431-446. https://doi.org/10.7476/9788523218812.0025

SIMMEL, G. On individuality and social forms. Chicago: The University of Chicago Press, 1971.

SOARES, M. L. A. Grafias Urbanas: a Cidade de vidro de Paul Auster. In: MARANDOLA JR., E; HOLZER, W.; LíVIA, O. (Orgs.) Qual o espaço do lugar? São Paulo: Perspectiva, 2014, p.173-190.

SOJA, E. W. Postmodern Geographies: The reassertion of space in critical social theory. Verso: London, 1989.

SOJA, E. W. En busca de la justicia espacial. Valencia: Tirant Humanidades, 2014.

SOUZA, M. L. Os conceitos fundamentais da pesquisa sócio-espacial. Rio de Janeiro: Bertrand Brasil, 2013.

SOUZA, J. A elite do atraso. Rio de janeiro: Leya, 2017.

TELLES, V. S. Trajetórias urbanas: fios de uma descrição da cidade. In: TELES, V et al. Nas tramas da cidade: trajetórias urbanas e seus personagens. São Paulo, Humanitas, 2006.

TURRA NETO, N. Espaço e lugar no debate sobre território. Geograficidade, v. 5, n. 1, p.52-59, 2015. https://doi.org/10.22409/geograficidade2015.51.a12918

WEBER, M. A 'objetividade' do conhecimento nas Ciências Sociais. São Paulo: Ática, 2006.

Recebido em: 12/07/2019

Aceito para publicação em: 27/09/2019 